Check for updates

Cite this: RSC Adv., 2018, 8, 33030

Received 28th June 2018

Accepted 18th September 2018

DOI: $10.1039 / \mathrm{c} 8 \mathrm{ra05544k}$

rsc.li/rsc-advances

\section{In situ approach of cementite nanoparticles encapsulated with nitrogen-doped graphitic shells as anode nanomaterials for $\mathrm{Li}$-ion and $\mathrm{Na}$-ion batteries $\dagger$}

\author{
$\mathrm{Na} \mathrm{Na}$ Li, $\$$ Zhao Min Sheng, (D) † $^{*}$ Hao Liang Tian, Cheng Kang Chang, Run Ping Jia \\ and Sheng Han (D)*
}

Novel $\mathrm{Fe}_{3} \mathrm{C}$ nanoparticles encapsulated with nitrogen-doped graphitic shells were synthesized by floating catalytic pyrolysis. Due to the short synthesis time and controllable pyrolytic temperature, the diameters of $\mathrm{Fe}_{3} \mathrm{C}$ core nanoparticles ranged from 5 to $15 \mathrm{~nm}$ ( $\mathrm{Fe}_{3} \mathrm{CaNGS900}$ prepared at $900{ }^{\circ} \mathrm{C}$ ) and the average thickness of $\mathrm{N}$-doped graphitic shells was $\sim 1.2 \mathrm{~nm}$, leading to their high electrochemical performance: specific capacity of $1300 \mathrm{~mA} \mathrm{~h} \mathrm{~g}$ at current density $0.2 \mathrm{~A} \mathrm{~g}^{-1}$, outstanding rate capability of $939 \mathrm{~mA} \mathrm{~h} \mathrm{~g}^{-1}$ at $3 \mathrm{~A} \mathrm{~g}^{-1}$, improved initial coulombic efficiency (Fe 3 C@NGS900: $72.1 \%$ vs. NGS900 (pure graphitic shells): 52\%) for lithium ion batteries (LIBs), and impressive long-term cycle performance (1399 $\mathrm{mA} \mathrm{h} \mathrm{g}^{-1}$ maintained at $3 \mathrm{~A} \mathrm{~g}^{-1}$ after 500 cycles for LIBs; $214 \mathrm{~mA} \mathrm{~h} \mathrm{~g}^{-1}$ maintained at $1 \mathrm{~A} \mathrm{~g}^{-1}$ after 500 cycles for sodium ion batteries).
Because of the fast development of portable electronic devices and hybrid electric vehicles, lithium ion batteries (LIBs) ${ }^{1-8}$ and sodium ion batteries (NIBs) ${ }^{9-16}$ with high energy/power density, good cycling performance, and lack of memory effects are in ever-increasing need. Due to the low theoretical capacity of carbon materials (graphite: $372 \mathrm{~mA} \mathrm{~h} \mathrm{~g}^{-1}$ ), ${ }^{\mathbf{8}, 17-22}$ optimizing the morphology of graphitic electrode materials has been important to improve specific capacity. ${ }^{1-7,23,24}$ On the other hand, chemical doping (e.g., N, S, B, P) is an effective strategy to raise their specific capacity by increasing conductivity or active sites for $\mathrm{Li}^{+}$or $\mathrm{Na}^{+}$storage. ${ }^{3,4,25-28}$ Additionally, metallic compounds (e.g., $\mathrm{Fe}_{3} \mathrm{C}$ ) have been also introduced into improving electrochemical performance of carbon anodes, because such materials are proposed to activate some components for reversible transformation of the solid electrolyte interface (SEI) and further benefit reversible capacity. ${ }^{13,16,29,30}$ Unfortunately, most of them have been prepared by complex methods including tedious synthetic steps or long-time annealing, ${ }^{6,17-19}$ from which, it is hard to prepare $\mathrm{Fe}_{3} \mathrm{C}$ particles with desirable small sizes. ${ }^{\mathbf{8}, 13,15,16}$ Thus, developing appropriate $\mathrm{Fe}_{3} \mathrm{C} / \mathrm{C}$ electrode materials still requires further research.

School of Materials Science and Engineering, Shanghai Institute of Technology, Shanghai 201418, China.E-mail: zmsheng@sit.edu.cn; Hansheng654321@sina.com; Fax: +86-21-60873439

$\dagger$ Electronic supplementary information (ESI) available. See DOI: 10.1039/c8ra05544k

$\ddagger$ N. N. L. and Z. M. S. contributed equally to this work.
In this work, $\mathrm{Fe}_{3} \mathrm{C}$ nanoparticles encapsulated with nitrogendoped graphitic shells ( $\left.\mathrm{Fe}_{3} \mathrm{C} @ N G S\right)$ were in situ approached from floating catalytic pyrolysis. Due to the short annealing time of the pyrolysis, $\mathrm{Fe}_{3} \mathrm{C} @$ NGSs was prepared with controllable sizes. Furthermore, the in situ approach led the graphitic shells just grew on the surface of $\mathrm{Fe}_{3} \mathrm{C}$ core nanoparticles, which improved electron transfer between the cores and the shells. Thus, such nanoparticles might be a superb electrode material towards high performance applications of LIBs and NIBs.

For preparing the $\mathrm{Fe}_{3} \mathrm{C} @$ NGSs with controllable sizes, floating catalytic pyrolysis was carried out to shorten synthetic time: the gas mixture was introduced into quartz pipe furnace, which was set at $700-1100^{\circ} \mathrm{C}$. For a typical experiment, nitrogen (flow rate: $\left.80 \mathrm{~L} \mathrm{~h}^{-1}\right)$, acetylene $\left(10 \mathrm{~mL} \mathrm{~min}{ }^{-1}\right)$ and ammonia $\left(100 \mathrm{~mL} \mathrm{~min}^{-1}\right)$ gases were embedded into iron pentacarbonyl held at $10^{\circ} \mathrm{C}$ to form the gas mixture. After the pyrolysis, $\mathrm{Fe}_{3}$ C@NGS was collected at the other end of the quartz pipe. The details of materials characterization and electrochemical measurements can be found in ESI. $\dagger$

As shown in transmission electron microscope (TEM) images of the prepared $\mathrm{Fe}_{3} \mathrm{C} @ N G S s$ (Fig. 1a-c and S1a of ESI $\dagger$ ), the metallic cores (dark section) are encapsulated with their shell (light section). The XRD results (Fig. 1d) shows the metallic core nanoparticles are $\mathrm{Fe}_{3} \mathrm{C}$. Thus, the sample prepared at 900 and $1100{ }^{\circ} \mathrm{C}$ have been marked with $\mathrm{Fe}_{3} \mathrm{C} @ N G S 900$ and $\mathrm{Fe}_{3}-$ C@NGS1100, respectively. However, the sample prepared at $700{ }^{\circ} \mathrm{C}$, which has been marked with FN@NGS700, has been oxidized in air at room temperature, because of its poor graphitic layers. Compared with XRD pattern of $\mathrm{Fe}_{3} \mathrm{C} @ N G S 900$, 


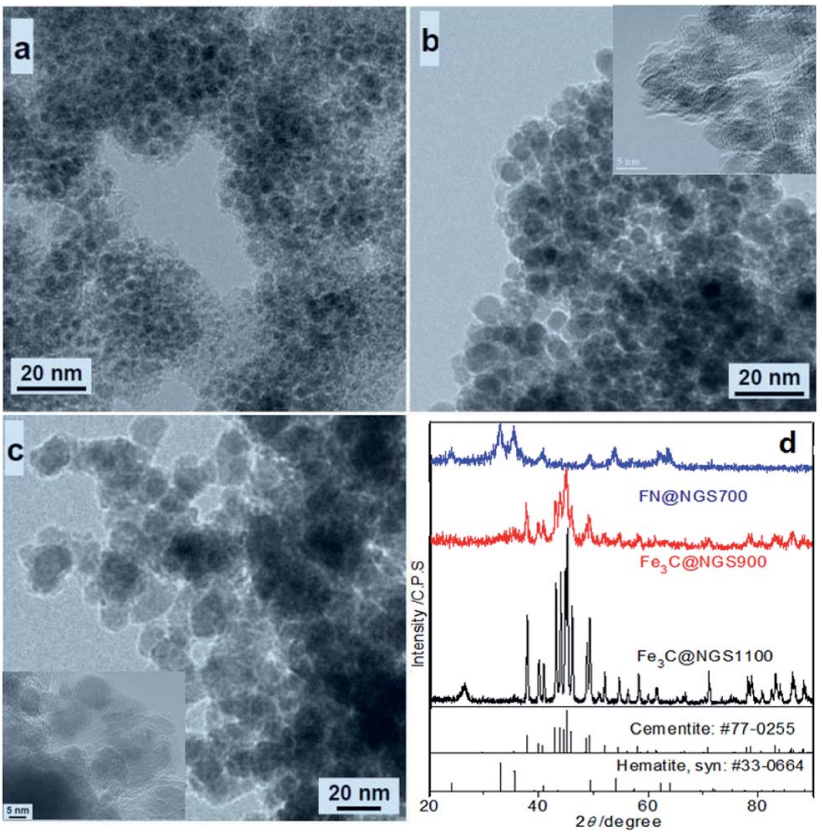

Fig. 1 (a) TEM images of core-shells nanoparticles (FN@NGS700) prepared at $700{ }^{\circ} \mathrm{C}$, TEM and HRTEM (inset) images of nanoparticles $\left(\mathrm{Fe}_{3} \mathrm{C}(\mathrm{aNGS900})\right.$ prepared at $900{ }^{\circ} \mathrm{C}$ (b) and nanoparticles $\left(\mathrm{Fe}_{3}-\right.$ CaNGS1100) prepared at $1100{ }^{\circ} \mathrm{C}$ (c) and (d) XRD patterns of coreshells nanoparticles prepared at different temperatures.

those peaks of $\mathrm{Fe}_{3} \mathrm{C} @ N G S 1100$ are much sharper indicating much bigger ferrous cores of $\mathrm{Fe}_{3} \mathrm{C} @ N G S 1100$. According to the TEM and high resolution TEM (HRTEM) images for $\mathrm{Fe}_{3^{-}}$ C@NGS900 (Fig. 1a-c, S1a, and b†), the diameter of the core nanoparticles is ranged from $5-15 \mathrm{~nm}$ and the average thickness of their shells is $\sim 1.2 \mathrm{~nm}$, respectively. Moreover, the spacing of the lattice fringes (Fig. S1a and $\mathrm{b}_{\dagger} \dagger$ ) is $\sim 0.34 \mathrm{~nm}$ corresponding to the characteristic (002) peak of graphite implying high graphitization of those shells. ${ }^{25,28,31}$ In the HRTEM images, every $\mathrm{Fe}_{3} \mathrm{C}$ cores is found to be a single crystal and encapsulated with the graphitic shell. The boundary between $\mathrm{Fe}_{3} \mathrm{C}$ cores and N-doped graphitic shells is continuous and distinguished, indicating $\mathrm{Fe}_{3} \mathrm{C}$ cores are tightly encapsulated with the graphitic shell.

$\mathrm{Fe}_{3} \mathrm{C} @$ NGS samples have been also analyzed by X-ray photoelectron spectroscopy (XPS), which suggests $\mathrm{Fe}_{3} \mathrm{C} @ N G S$ samples contain Fe, C, $\mathrm{O}$ and $\mathrm{N}$ atoms (FN@NGS700: $\mathrm{C}$ content of $16.3 \mathrm{wt} \%$, Fe content of $54.6 \mathrm{wt} \%, \mathrm{~N}$ content of $1.6 \mathrm{wt} \%$ and $\mathrm{O}$ content of $27.5 \mathrm{wt} \% ; \mathrm{Fe}_{3} \mathrm{C} @ N G S 900$ : C content of $26 \mathrm{wt} \%, \mathrm{Fe}$ content of $67 \mathrm{wt} \%, \mathrm{~N}$ content of $2 \mathrm{wt} \%$ and $\mathrm{O}$ content of $5 \mathrm{wt} \%$; $\mathrm{Fe}_{3} \mathrm{C} @ N G S 1100: \mathrm{C}$ content of $33.7 \mathrm{wt} \%, \mathrm{Fe}$ content of $52 \mathrm{wt} \%, \mathrm{~N}$ content of $2.3 \mathrm{wt} \%$ and $\mathrm{O}$ content of $7 \mathrm{wt} \%$ ). According to XPS results of $\mathrm{Fe}_{3} \mathrm{C} @ N G S 900$, the weight ratio of $\mathrm{Fe}_{3} \mathrm{C}$ cores and graphitic shells is $3.39: 1$. Additionally, the element contents of $\mathrm{Fe}_{3} \mathrm{C} @ N G S$ samples are different due to their morphology and structure (Fig. 1). Higher O content of FN@NGS700 is because its ferrous cores have been oxidized, and thick-walled graphitic shells ( $\sim 3 \mathrm{~nm})$ of $\mathrm{Fe}_{3} \mathrm{C} @ N G S 1100$ leads to its higher $\mathrm{C}$ content, as XPS can only measure element contents of surface of samples.
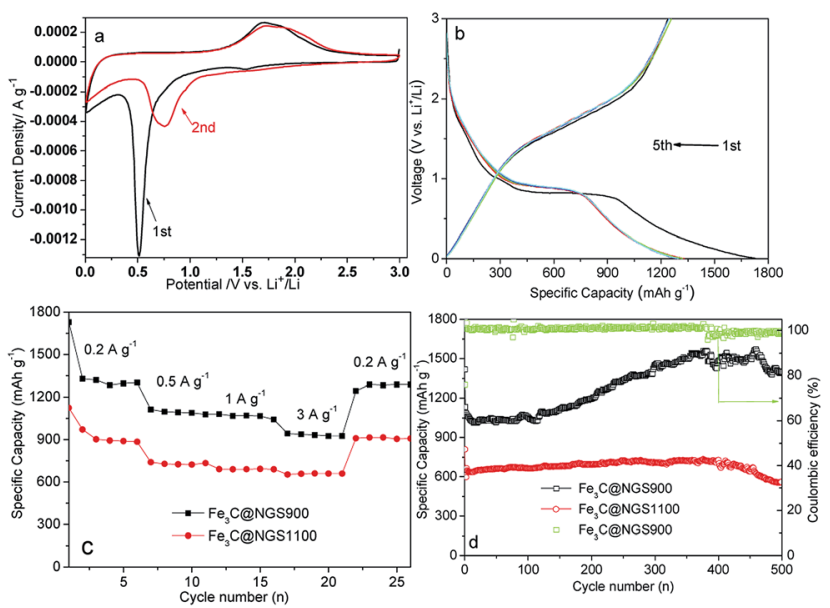

Fig. 2 Electrochemical performance of prepared nanoparticles as anodes for LIBs: CV profile (a) of $\mathrm{Fe}_{3} \mathrm{CaNGS900}$ at a scan rate of $0.1 \mathrm{mV} \mathrm{s}^{-1}$ between 0.01-3 V vs. $\mathrm{Li}^{+} / \mathrm{Li}$ for the 1st-2nd charge/ discharge cycles; (b) the galvanostatic charge-discharge profiles of $\mathrm{Fe}_{3} \mathrm{C}$ (aNGS900; (c) charge-discharge cycling performance of $\mathrm{Fe}_{3}$ C@NGS core-shell nanoparticles at different current densities from 0.2 to $3 \mathrm{~A} \mathrm{~g}^{-1}$ at room temperature; (d) cycling performance of $\mathrm{Fe}_{3}$ C@NGS at $3 \mathrm{~A} \mathrm{~g}^{-1}$.

The electrochemical properties of the $\mathrm{Fe}_{3} \mathrm{C} @$ NGS-based electrodes have been shown in Fig. 2 and 3 . Since FN@NGS700 sample has been completely oxidized, electrochemical properties of ferrous oxide has not been measured. The cyclic voltammetry (CV) curves of $\mathrm{Fe}_{3} \mathrm{C} @ N G S 900$-based electrode show details of possible lithium storage process. Besides the similar peak $(0.5 \mathrm{~V})$ in the initial cycle for the SEI formation, two reduction peaks are located at 0.7 and $\sim 1.5 \mathrm{~V}$, corresponding to the reduction of some SEI components $\left(\mathrm{Li}^{+}\right.$ insertion). During the $\mathrm{Li}^{+}$extraction process, the corresponding oxidation peaks is found to shift from $\sim 1.7$ to $\sim 1.9 \mathrm{~V}$. The almost overlapped oxidation peaks demonstrate good reversibility and cycling stability of core-shell $\mathrm{Fe}_{3} \mathrm{C} @$ NGS. ${ }^{15}$ As shown in Fig. 2b, the galvanostatic discharge-charge (GDC) profiles of $\mathrm{Fe}_{3} \mathrm{C} @ N G S 900$ in a voltage range of $0.005-3 \mathrm{~V}\left(v s . \mathrm{Li}^{+} / \mathrm{Li}\right)$ exhibits the typical shape of $\mathrm{Fe}_{3} \mathrm{C} @ N G S$-based anodes, and $\mathrm{Fe}_{3} \mathrm{C} @ N G S 900$ delivers initial charge and discharge capacities of 1246.7 and $1729.1 \mathrm{~mA} \mathrm{~h} \mathrm{~g}^{-1}$, respectively. The initial columbic efficiency (CE) reaches up to $72.1 \%$ which is higher than $52 \%$ of pure graphitic shells. ${ }^{3}$ For $\mathrm{Fe}_{3} \mathrm{C} @$ NGSs electrode, the phenomenon of capacity increment is related to growing reversibly SEI film via the decomposition of electrolyte due to the catalysis of $\mathrm{Fe}_{3} \mathrm{C} \cdot{ }^{16,29} \mathrm{From}$ the second cycle, the shape of the discharge profiles changes with respect to that of the first cycle, which may be due to the modification of the SEI film. ${ }^{12}$

The excellent rate capability of $\mathrm{Fe}_{3} \mathrm{C} @$ NGS-based anodes have been investigated by testing charge/discharge at current densities of 0.2, 0.5, 1 and $3 \mathrm{~A} \mathrm{~g}^{-1}$ for every 5 cycles (Fig. 2c). At the corresponding rates, the reversible capacities are 1300, 1101, 1062 and $939 \mathrm{~mA} \mathrm{~h} \mathrm{~g}{ }^{-1}$ for $\mathrm{Fe}_{3} \mathrm{C} @ N G S 900 ; 925,721,690$ and $663 \mathrm{~mA} \mathrm{~h} \mathrm{~g}^{-1}$ for $\mathrm{Fe}_{3} \mathrm{C} @ N G S 1100$, indicating the smaller size of the $\mathrm{Fe}_{3} \mathrm{C}$ nanoparticles might enhance their 

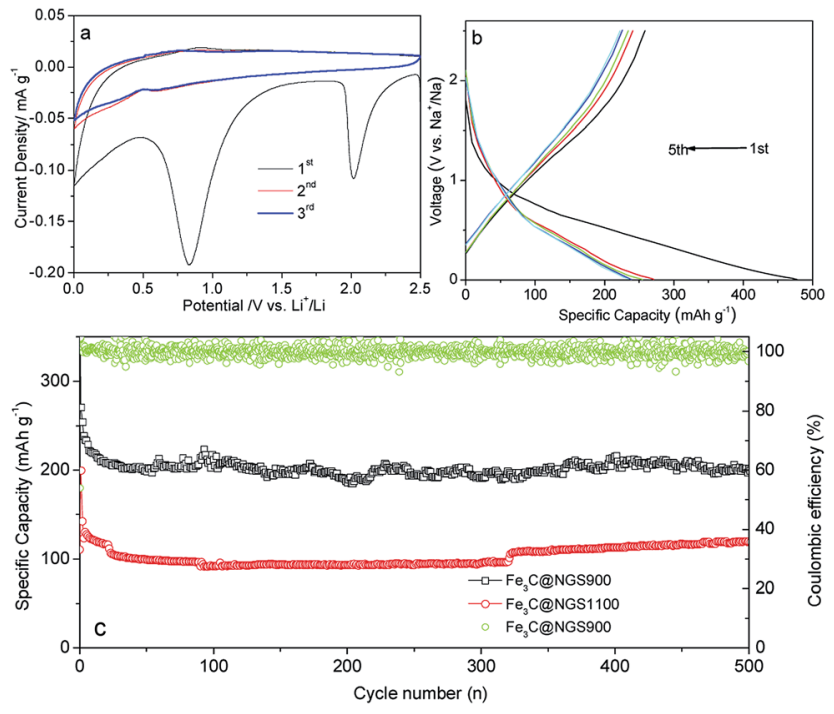

Fig. 3 Electrochemical performance of the prepared nanoparticles as anodes for NIBs: (a) CV profile of $\mathrm{Fe}_{3} \mathrm{C}$ aNGS900 at a scan rate of $0.1 \mathrm{mV} \mathrm{s}^{-1}$ between $0.01-2.5 \mathrm{~V}$ vs. $\mathrm{Na}^{+} / \mathrm{Na}$ for the 1st-3rd charge/ discharge cycles. (b) The galvanostatic charge-discharge profiles of $\mathrm{Fe}_{3} \mathrm{C} @ \mathrm{NGS900;}$ (c) cycling performance of $\mathrm{Fe}_{3} \mathrm{C} @ \mathrm{NGS}$ at a current density of $1 \mathrm{~A} \mathrm{~g}^{-1}$, and the corresponding columbic efficiency.

electrochemical capability. Compared with reported pure graphitic shells (NGS900 prepared by removing $\mathrm{Fe}_{3} \mathrm{C}$ cores of $\left.\mathrm{Fe}_{3} \mathrm{C} @ N G S 900\right),{ }^{3}$ the core-shell nanoparticles ( $\left.\mathrm{Fe}_{3} \mathrm{C} @ N G S 900\right)$ exhibits impressive rate performances (NGS900: $760 \mathrm{~mA} \mathrm{~h} \mathrm{~g}^{-1}$ at $0.5 \mathrm{~A} \mathrm{~g}^{-1}, 620 \mathrm{~mA} \mathrm{~h} \mathrm{~g}^{-1}$ at $1 \mathrm{~A} \mathrm{~g}^{-1}$ and $340 \mathrm{~mA} \mathrm{~h} \mathrm{~g}{ }^{-1}$ at $5 \mathrm{~A} \mathrm{~g}^{-1}$ ), which might be caused by $\mathrm{Fe}_{3} \mathrm{C}$, as a good conductor of electricity, can effectively improve electrical conductivity of carbon electrode material. ${ }^{13}$ Calculated from eqn (1) of ESI, $\dagger$ specific capacity of $\mathrm{Fe}_{3} \mathrm{C}$ cores of $\mathrm{Fe}_{3} \mathrm{C} @ N G S 900$ can be evaluated (1199 $\mathrm{mA} \mathrm{h} \mathrm{g}^{-1}$ at $0.5 \mathrm{~A} \mathrm{~g}^{-1}$ and $1193 \mathrm{~mA} \mathrm{~h} \mathrm{~g}^{-1}$ at $1 \mathrm{~A} \mathrm{~g}^{-1}$, respectively). Based on the conversion mechanism for lithium storage, if possible, $\mathrm{Fe}_{3} \mathrm{C}$ can store only $1 / 6 \mathrm{Li}$ per unit $\left(\sim 26 \mathrm{~mA} \mathrm{~h} \mathrm{~g}{ }^{-1}\right),{ }^{15}$ which is negligible regarding to the high capacity of $\sim 1300 \mathrm{~mA} \mathrm{~h} \mathrm{~g}{ }^{-1}$. The specific capacity of $\mathrm{Fe}_{3} \mathrm{C}$ is larger than what it should be, which might be resulted from the pseudocapacity on the interface between the material and the electrolyte. ${ }^{16}$ For evaluating $\mathrm{N}$ doping structure in the graphitic shells, $\mathrm{Fe}_{3} \mathrm{C} @ N G S$ samples have been prepared with different percent of doping content at $900{ }^{\circ} \mathrm{C}$ by introducing ammonia

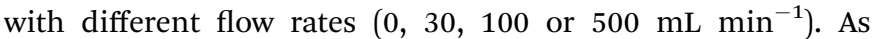
a result, $\mathrm{Fe}_{3} \mathrm{C} @ G S 900$ prepared without ammonia has graphitic shells without $\mathrm{N}$-doping leading to its poor electrochemical performance: at current densities of $0.2,0.5,1$ and $3 \mathrm{~A} \mathrm{~g}^{-1}$, its reversible capacities are 575, 492, 458 and $402 \mathrm{~mA} \mathrm{~h} \mathrm{~g}^{-1}$ (Fig. S4 $\uparrow$ ); the performances of $\mathrm{Fe}_{3} \mathrm{C} @ N G S 900$ (ammonia flow rate: $100 \mathrm{~mL} \mathrm{~min}^{-1}$; content of $\left.\mathrm{N}: 2 \mathrm{wt} \%\right)$ and $\mathrm{Fe}_{3} \mathrm{C} @ N G S 900 \mathrm{~A}$

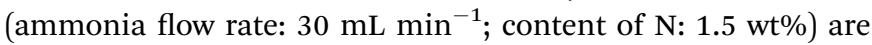
similar; the sample prepared with ammonia flow rates of 500 $\mathrm{mL} \mathrm{min}^{-1}$ (FN@NGS900B) was violent oxidized to ferrous oxide in the air. Hence, $\mathrm{N}$ doping structure in graphitic shells has been confirmed to enhance diffusion.

The long-term cycling performance of these two electrodes also has been investigated in Fig. 2d. The $\mathrm{Fe}_{3} \mathrm{C} @ N G S-b a s e d$ anode exhibits a favorable reversible capacity, which can reach $1399 \mathrm{~mA} \mathrm{~h} \mathrm{~g}^{-1}$ after 500 discharge/charge cycles at $3.0 \mathrm{~A} \mathrm{~g}^{-1}$, showing high capacity retention with CE of $\sim 100 \%$. The capacities of $\mathrm{Fe}_{3} \mathrm{C}$ samples increases with cycle number rising (from 120 to 450 ), which might be attributed to the pseducapacity presented by the $\mathrm{Fe}_{3} \mathrm{C}^{16}$

To better study the kinetic properties of $\mathrm{Fe}_{3} \mathrm{C} @ N G S 900$ and $\mathrm{Fe}_{3} \mathrm{C} @ N G S 1100$, Fig. S3 of ESI $\dagger$ shows the Nyquist plots and equivalent circuit obtained from electrochemical impedance spectroscopy (EIS) measurements. Here, $R_{\mathrm{s}}$ represents the ohmic resistance of the battery. Constant phase element (CPE) represents the double layer capacitive reactance between the electrode materials and the electrolyte. The semicircles and straight lines correspond to the electrochemical polarization impedance $\left(R_{\mathrm{p}}\right)$ and Warburg resistance $(W)$, respectively. ${ }^{32}$ Both the fitted $R_{\mathrm{S}}$ value $(5.526 \Omega)$ and $R_{\mathrm{p}}$ value $\left(20.826 \Omega\right.$ ) for $\mathrm{Fe}_{3}$ C@NGS900 electrode is much lower than that $\mathrm{Fe}_{3} \mathrm{C} @ N G S 1100$ electrode $\left(R_{\mathrm{s}}: 8.501 \Omega ; R_{\mathrm{p}}: 43.665 \Omega\right)$, indicating the superior redox kinetics in the $\mathrm{Fe}_{3} \mathrm{C} @ N G S 900$ composite.

In order to study the electrochemical properties of the $\mathrm{Fe}_{3}$ C@NGSs electrode as anodes for NIBs, CV analysis has been carried out at a scanning rate of $0.1 \mathrm{mV} \mathrm{s}^{-1}$ between 0.005 and $2.5 \mathrm{~V} v s . \mathrm{Na}^{+} / \mathrm{Na}$. As shown in Fig. 3a, there are two irreversible reduction peaks around $2.02 \mathrm{~V}$ and $0.83 \mathrm{~V}$ found during the initial cathodic scan, which could be ascribed to the interaction of $\mathrm{Na}$ ions with specific functional groups and the decomposition of electrolyte along with the formation of SEI film on the electrode surfaces. ${ }^{33,34}$ For the subsequent cycles, the peak at $2.02 \mathrm{~V}$ disappears and the peak at $0.83 \mathrm{~V}$ shifts to $0.60 \mathrm{~V}$. For the anodic scan, the main oxidation peak ranging from about $0.47 \mathrm{~V}$ to $1.28 \mathrm{~V}$ is supposed to be the desodiation reactions. ${ }^{35}$ Fig. $3 \mathrm{~b}$ depicts the GDC curves of the $\mathrm{Fe}_{3} \mathrm{C} @$ NGS900-based electrode for the 1st-5th cycle at current density of $0.1 \mathrm{~A} \mathrm{~g}^{-1}$. The large irreversible capacity in the 1st cycle is attributed to the SEI formation and the irreversible insertion of sodium ion with a relatively large ionic radius. ${ }^{22,23}$ Following the first cycle, the charge-discharge curves become more linear which exhibits a higher and more stable CE indicating a stable SEI layer formed in the first cycle.

Meanwhile, cycling performance of $\mathrm{Fe}_{3} \mathrm{C} @ N G S-b a s e d$ anodes for NIBs have been shown in Fig. 3c. In the extended cycling test at $1 \mathrm{~A} \mathrm{~g}^{-1}$, a reversible capacity $214 \mathrm{~mA} \mathrm{~h} \mathrm{~g}{ }^{-1}$ of $\mathrm{Fe}_{3} \mathrm{C} @ N G S 900$ electrode is still maintained after 500 cycles, which is $\sim 2$ times the capacity delivered by the $\mathrm{Fe}_{3} \mathrm{C} @ N G S 1100$ indicating excellent cycling stability of $\mathrm{Fe}_{3} \mathrm{C} @$ NGS900. Thus, $\mathrm{Fe}_{3} \mathrm{C} @$ NGS-base anodes holds great potential as a promising candidate compared with other carbonaceous anode materials for NIBs (113 $\mathrm{mA} \mathrm{h} \mathrm{g}{ }^{-1}$ at $1 \mathrm{~A} \mathrm{~g}^{-1}$ (modified PFR/C), ${ }^{36}$ $188.6 \mathrm{~mA} \mathrm{~h} \mathrm{~g}^{-1}$ at $0.1 \mathrm{~A} \mathrm{~g}^{-1}$ after 300 cycles (S/C), ${ }^{33} 150 \mathrm{~mA} \mathrm{~h} \mathrm{~g}^{-1}$ at $1 \mathrm{~A} \mathrm{~g}^{-1}$ after 200 cycles (S/graphene) $)^{35}$ ).

It is noticed that the excellent electrochemical performance of the prepared $\mathrm{Fe}_{3} \mathrm{C} @$ @GSs is apparently ascribed to their novel structure. First, because of in situ growing graphitic shells on the surface of $\mathrm{Fe}_{3} \mathrm{C}$ during floating catalytic pyrolysis, contact between $\mathrm{Fe}_{3} \mathrm{C}$ cores and graphitic shells effectively increases, leading to lower contact resistance and faster electron transfer between the cores and the shells, comparing with traditional 
ferrous/carbon composites generated by multistep carbonization approach. ${ }^{\mathbf{8 , 1 3 , 1 5 , 1 6}}$ Second, due to floating catalytic pyrolysis, sizes of $\mathrm{Fe}_{3} \mathrm{C}$ core nanoparticles have been under control $\left(\mathrm{Fe}_{3}-\right.$ C@NGS900: 5-15 nm vs. $\mathrm{Fe}_{3} \mathrm{C} @ N G S 1100:$ 15-40 nm). Smaller size of $\mathrm{Fe}_{3} \mathrm{C}$ core nanoparticles might increase surface of $\mathrm{Fe}_{3} \mathrm{C}$ nanoparticles, leading to distinguished improvement of their electrochemical performance (Fig. 2 and 3), due to active sites for $\mathrm{Li}^{+}$or $\mathrm{Na}^{+}$storage rising. For comparison, sizes of reported $\mathrm{Fe}_{3} \mathrm{C}$ composites have been listed: $\mathrm{Fe}_{3} \mathrm{C} @ \mathrm{C}$ : $60 \mathrm{~nm}$ nanoparticles encapsulated with $4 \mathrm{~nm}$ carbon shells; ${ }^{8} \mathrm{Fe}_{3} \mathrm{C} @ P C: 29$ $\pm 5 \mathrm{~nm}$ nanoparticles embedded in $300 \mathrm{~nm}$ porous carbon; ${ }^{16}$ $\mathrm{Fe}_{3} \mathrm{C} / \mathrm{C}: 300 \mathrm{~nm} ;^{13} \mathrm{Fe} @ \mathrm{Fe}_{3} \mathrm{C} / \mathrm{C}: 28-58 \mathrm{~nm} \mathrm{Fe}_{3} @ \mathrm{Fe}_{3} \mathrm{C}$ nanoparticles. ${ }^{15}$ Third, introducing $\mathrm{Fe}_{3} \mathrm{C}$ to electrode material can promote the reversible formation/decomposition of the SEI film, causing improvement of initial CE (72.1\% vs. $52 \%)$ for LIBs, due to the catalysis function of $\mathrm{Fe}_{3} \mathrm{C} .{ }^{\mathbf{1 6 , 2 9}}$ Fourth, due to in situ $\mathrm{N}$-doping $(\sim 2 \mathrm{wt} \%$ ) during their floating catalytic pyrolysis, such defects of the graphitic shells might offer lots channels for fast diffusion of electrolyte and $\mathrm{Li}^{+} / \mathrm{Na}^{+}$into those nanoparticles. Fifth, such prepared core-shell nanoparticles have ultra thin-walled graphitic shells ( $1.2 \mathrm{~nm}$ shown in Fig. 1d), which shorten the diffusion route of ions and electrolyte. All above confirm $\mathrm{Fe}_{3} \mathrm{C} @$ NGS900 has novel structure towards the electrochemical applications, compared with the reported works: $\mathrm{Fe} @ \mathrm{Fe}_{3} \mathrm{C} / \mathrm{C}$ sample was prepared by sol-gel and carbonization approach, and whether its pure Fe cores was good for $\mathrm{Li}^{+}$storage was doubtful; ${ }^{\mathbf{1 5}}$ the $\mathrm{Fe}_{3} \mathrm{C} @ \mathrm{C}$ nanoparticles were prepared with no doping carbon shells; ${ }^{8}$ the graphitization of carbon structure was doubtful, when ferrous/carbon composites were prepared by polymerization-carbonization of iron phthalocyanine $^{\mathbf{1 3}}$ or hydrothermal method-carbonization. ${ }^{\mathbf{1 6}}$ Thus, the $\mathrm{Fe}_{3} \mathrm{C} @ N G S 900$ performs better $\left(1300 \mathrm{~mA} \mathrm{~h} \mathrm{~g}{ }^{-1}\right.$ at current density of $0.2 \mathrm{~A} \mathrm{~g}^{-1} ; 939 \mathrm{~mA} \mathrm{~h} \mathrm{~g}^{-1}$ at $3 \mathrm{~A} \mathrm{~g}^{-1}$ ) than many reported ferrous/carbon composite anode materials for LIBS $\left(0.2 \mathrm{~A} \mathrm{~g}^{-1}:<382\left(\mathrm{Fe} @ \mathrm{Fe}_{3} \mathrm{C} / \mathrm{C}\right),{ }^{15} \sim 480\left(\mathrm{Fe}_{3} \mathrm{C} / \mathrm{C}\right),{ }^{8} 787.9\left(\mathrm{Fe}_{2} \mathrm{O}_{3} /\right.\right.$ C) ${ }^{5} \sim 850 \quad\left(\mathrm{Fe}_{3} \mathrm{O}_{4} / \mathrm{C}\right),{ }^{19} \quad 873 \quad(\mathrm{~N}, \mathrm{~S} / \mathrm{C}),{ }^{36}$ and $881 \quad\left(\mathrm{Fe}_{3} \mathrm{O}_{4} /\right.$ $\mathrm{C})^{9} \mathrm{~mA} \mathrm{~h} \mathrm{~g}^{-1}$; $3 \mathrm{~A} \mathrm{~g}^{-1}: \sim 300\left(\mathrm{Fe}_{2} \mathrm{O}_{3} @ \mathrm{C}\right),{ }^{18} \sim 370(\mathrm{FeS} @ \mathrm{C})^{21}$ and $\left.\sim 612\left(\mathrm{Fe}_{2} \mathrm{O}_{3} / \mathrm{C}\right)^{14} \mathrm{~mA} \mathrm{~h} \mathrm{~g}^{-1}\right)$.

\section{Conclusions}

In summary, novel $\mathrm{Fe}_{3} \mathrm{C}$ nanoparticles encapsulated with nitrogen-doped graphitic shells were synthesized by floating catalytic pyrolysis. Due to the short synthetic time and controllable pyrolytic temperature, the size diameters of $\mathrm{Fe}_{3} \mathrm{C}$ core nanoparticles were ranged from 5 to $15 \mathrm{~nm}$ ( $\mathrm{Fe}_{3} \mathrm{C} @$ NGS900 prepared at $900{ }^{\circ} \mathrm{C}$ ) and average thickness of $\mathrm{N}$-doped graphitic shells was $\sim 1.2 \mathrm{~nm}$. The unique nanoparticles contributed to their high electrochemical performance: specific capacity of $1300 \mathrm{~mA} \mathrm{~h} \mathrm{~g}{ }^{-1}$ at current density $0.2 \mathrm{~A} \mathrm{~g}^{-1}$, outstanding rate capability of $939 \mathrm{~mA} \mathrm{~h} \mathrm{~g}{ }^{-1}$ at $3 \mathrm{~A} \mathrm{~g}^{-1}$, and improved initial columbic efficiency ( $\mathrm{Fe}_{3} \mathrm{C} @ N G S 900: 72.1 \%$ vs. NGS900 (pure graphitic shells): 52\%) for LIBs; impressive long-time cycle performance (1399 $\mathrm{mA} \mathrm{h} \mathrm{g}^{-1}$ maintained after 500 at $3 \mathrm{~A} \mathrm{~g}^{-1}$ for LIBs; $214 \mathrm{~mA} \mathrm{~h} \mathrm{~g}^{-1}$ maintained after 500 at $1 \mathrm{~A} \mathrm{~g}^{-1}$ for NIBs). The excellent electrochemical performance as well as the facile synthesis route makes $\mathrm{Fe}_{3} \mathrm{C} @ N G S$ promising for application in superior performance LIBs, NIBs and other high-level applications. ${ }^{\mathbf{1 3 , 3 7 - 4 5}}$

\section{Conflicts of interest}

There are no conflicts.

\section{Acknowledgements}

This research was supported by Pujiang Talent Project (13PJ1407400) and Funds $(14520503100,15520503400)$ from Science and Technology Commission of Shanghai Municipality, Fund (LM201740) from Shanghai association for the promotion of scientific and technological achievements, Funds from Shanghai institute of technology (ZQ2018-14, XTCX2017-1) and research fund (project \#21306113) from the National Natural Science Foundation of China.

\section{References}

1 P. Sengodu and A. D. Deshmukh, RSC Adv., 2015, 5, 42109.

2 C. Ma, J. Dong, Y. Zhao, J. Li and H. Chen, Carbon, 2016, 110, 180.

3 C. Y. Hong, Z. M. Sheng, M. H. Hu, X. Y. Dai, C. K. Chang, Q. Z. Chen and D. Y. Zhang, RSC Adv., 2016, 6, 59896.

4 H. Yue, F. Li, Z. B. Yang, J. Tang, X. W. Li and D. Y. He, Mater. Lett., 2014, 120, 39.

5 C. P. Gu, X. J. Song and S. M. Zhang, J. Alloys Compd., 2017, 714, 6.

6 J. X. Li, W. W. Wen, M. Z. Zou, Z. G. Huang and L. H. Guan, Electrochim. Acta, 2015, 153, 300.

7 B. Joshi, J. G. Lee, E. Samuel, H. S. Jo, T. Kim and M. T. Swihart, J. Alloys Compd., 2017, 726, 114.

8 Y. G. Huang, X. L. Lin, X. H. Zhang, Q. C. Pan, Z. X. Yan, H.-Q. Wang, J.-J. Chen and Q.-Y. Li, Electrochim. Acta, 2015, 178, 468.

9 Q. H. Wu, R. F. Zhao, X. Zhang, W. L. Li and M. Chen, J. Power Sources, 2017, 359, 7.

10 Y. Z. Yan, H. L. Tang, J. S. Li, F. Wu, M. Pan, Z. Z. Xie and D. Y. Qu, J. Colloid Interface Sci., 2017, 495, 157.

11 X. Zhang, S. Han, C. Fan, L. Li and W. Zhang, Mater. Lett., 2015, 138, 259.

12 Y. L. Tan, K. Zhu, D. Li, F. Bai and P. Zhang, Chem. Eng. J., 2014, 258, 93.

13 X. Y. Zhao, D. G. Xia, J. C. Yue and S. Z. Liu, Electrochim. Acta, 2014, 116, 292.

14 H. N. Li, X. F. Zhu, H. Sitinamaluwa, S. Q. Zhang and C. Yan, J. Alloys Compd., 2017, 714, 425.

15 L. Su, Z. Zhou and P. Shen, Electrochim. Acta, 2013, 87, 180. 16 S. H. Chen, J. F. Wu, R. H. Zhou, L. Zuo, P. Li, Y. H. Song and L. Wang, Electrochim. Acta, 2015, 180, 78.

17 Y. Yang, J. Li, D. Chen and J. Zhao, ACS Appl. Mater. Interfaces, 2016, 8, 26730.

18 T. Zhang, C. L. Zhu, Y. S. Shi, Y. Li, S. M. Zhu and D. Zhang, Mater. Lett., 2017, 205, 10.

19 N. Zhang, C. Chen, X. H. Yan, Y. Huang, J. Li, J. M. Ma and D. Ng, Electrochim. Acta, 2017, 223, 39. 
20 X. Qin, H. Zhang, J. Wu, X. Chu, Y. B. He, B. Li and F. Kang, Carbon, 2015, 87, 347.

21 X. Wei, W. H. Li, J. Shi, L. Gu and Y. Yu, ACS Appl. Mater. Interfaces, 2015, 7, 27804.

22 Z. L. Xu, S. S. Yao, J. Cui, L. M. Zhou and J. K. Kim, Energy Storage Mater., 2017, 8, 10.

23 Y. H. Qu, Z. A. Zhang, K. Du, W. Chen and Y. Q. Lai, Carbon, 2016, 105, 103.

24 G. Maurina, C. Bousqueta, F. Henna, P. Bernierb and B. Simonc, Chem. Phys. Lett., 1999, 312, 14.

25 Z. M. Sheng, C. X. Guo and C. M. Li, Electrochem. Commun., 2012, 19, 77.

26 Z. M. Sheng and J. N. Wang, Carbon, 2009, 47, 3271.

27 L. Su, Z. Zhou and P. Shen, J. Phys. Chem. C, 2012, 116, 23974.

28 Z. M. Sheng, X. J. Chang, Y. H. Chen, R. P. Jia and S. Han, RSC Adv., 2017, 7, 42083.

29 M. Z. Zou, L. L. Wang, J. X. Lia and L. H. Guan, Electrochim. Acta, 2017, 233, 85.

30 J. Zhang, K. Wang, Q. Xu, Y. Zhou, F. Cheng and S. Guo, ACS Nano, 2015, 9, 3369.

31 Z. M. Sheng, M. H. Hu, X. Y. Dai, C. Y. Hong and C. K. Chang, Microporous Mesoporous Mater., 2016, 234, 224.

32 D. D. Yang, J. Shi, J. H. Shi and H. B. Yang, Electrochim. Acta, 2018, 259, 1081.

33 X. D Shi, Y. X. Chen, Y. Q. Lai, K. Zhang and Z. A. Zhang, Carbon, 2017, 123, 250.
34 W. Li, M. Zhou, H. M. Li, K. L. Wang, S. J. Cheng and K. Jiang, Energy Environ. Sci., 2015, 8, 2916.

35 X. L. Wang, G. Li, F. M. Hassan, J. D. Li and Z. W. Chen, Nano Energy, 2015, 15, 746.

36 Z. Z. Qiu, Y. M. Lin, H. L. Xin, P. Han, D. Z. Li, B. Yang and J. Xu, Carbon, 2018, 126, 85.

37 Z. L. Yu, S. Xin, Y. You, L. Yu, Y. Lin and J. B. Goodenough, J. Am. Chem. Soc., 2016, 138, 14915.

38 Z. M. Sheng, C. Y. Hong, X. Y. Dai, C. K. Chang, J. B. Chen and Y. Liu, J. Nanosci. Nanotechnol., 2015, 15, 3111.

39 B. W. Byles, P. West, D. A. Cullen, K. L. More and E. Pomerantseva, RSC Adv., 2015, 5, 106265.

40 Z. M. Sheng, C. Y. Hong, N. N. Li, Q. Z. Chen and R. P. Jia, Electrochim. Acta, 2018, 259, 1104.

41 X. Y. Xie, X. J. He, X. L. Shao and S. A. Dong, Electrochim. Acta, 2017, 246, 634.

42 H. Zhang, X. Sun, X. Huang and L. Zhou, Nanoscale, 2015, 7, 3270.

43 X. B. Wang, P. Zhang, J. J. Gao, X. D. Chen and H. Yang, Dyes Pigm., 2015, 112, 305.

44 Z. H. Liu, D. D. Guan, Q. Yu, L. Xu, Z. C. Zhuang, T. Zhu, D. Y. Zhao, L. Zhou and L. Q. Mai, Energy Storage Mater., 2018, 13, 112.

45 C. J. Tang, Y. N. Liu, C. Xu, J. X. Zhu, X. J. Wei, L. Zhou, L. He, W. Yang and L. Q. Mai, Adv. Funct. Mater., 2018, 28, 1704561. 